Lars Gutow · Julia Strahl • Christian Wiencke

Heinz-Dieter Franke • Reinhard Saborowski

\title{
Behavioural and metabolic adaptations of marine isopods to the rafting life style
}

Received: 20 July 2005 / Accepted: 16 January 2006/Published online: 7 February 2006

(C) Springer-Verlag 2006

\begin{abstract}
Rafting on floating objects is a common dispersal mechanism for many marine invertebrates. In order to identify adaptations to the rafting life style, we compared behavioural and metabolic characteristics of two isopods, the obligate rafter Idotea metallica and the facultative rafter Idotea baltica. In laboratory experiments, I. metallica showed low locomotive activity and a tight association to the substratum. Idotea baltica, in contrast, was more active with more frequent excursions in the surrounding water column. Oxygen consumption rates were similar in both species. Idotea metallica fed on zooplankton making this species widely independent of autochthonous food resources of the raft. Feeding rates and digestive enzyme activities were low in I. metallica. Reduced egestion rates may indicate slow gut passage and, thus, efficient resorption of nutrients. Efficient food utilization and the ability to accumulate high amounts of storage products, i.e. lipids, indicate a possible adaptation of I. metallica to low food availability or starvation. The feeding behaviour of I. baltica, in contrast, was more herbivorous and appeared wasteful and inefficient. Low lipid contents in I. baltica also indicate poor storage reserves. Thus, I. baltica requires a permanent access to food.
\end{abstract}

Communicated by O. Kinne, Oldendorf/Luhe

L. Gutow $(\bowtie) \cdot$ J. Strahl $\cdot$ C. Wiencke

Alfred Wegener Institute for Polar and Marine Research,

P.O. Box 1201 61, 27515 Bremerhaven, Germany

E-mail: lgutow@awi-bremerhaven.de

Tel.: +49-471-48311708

Fax: +49-471-48311724

J. Strahl

Department of Marine Zoology, University of Bremen,

P.O. Box 3304 40, 28334 Bremen, Germany

H.-D. Franke · R. Saborowski

Alfred Wegener Institute for Polar and Marine Research, Biologische Anstalt Helgoland, P.O. Box 180,

27483 Helgoland, Germany

\section{Introduction}

Seven isopod species of the genus Idotea form resident populations around the island of Helgoland (German Bight, North Sea; Franke et al. 1999). They are distributed benthically along the coast from the supratidal down to subtidal habitats (Naylor 1972). The distribution of Idotea baltica and Idotea emarginata is primarily the result of interspecific competition and subsequent habitat segregation (Franke and Janke 1998). Although they prefer benthic habitats, all species also raft on floating objects at the sea surface; most of them, however, only sporadically. Only I. baltica is abundant on floating macroalgae in the German Bight, especially on brown algae of the order Fucales, with average numbers of about 90 adult animals per $\mathrm{kg}$ seaweed (Franke et al. 1999). Since 1994 another species, I. metallica, has occurred regularly in small numbers on floating objects in the North Sea. Gutow and Franke (2001) showed that I. metallica is only a summer resident. Populations go extinct in winter because temperatures are too low for reproduction. Nevertheless, due to repeated annual re-introduction, I. metallica has become a regular member of the isopod community of the German Bight.

Idotea metallica lives exclusively on often abiotic floating objects (Moreira 1972; Tully and Ó Ceídigh 1986) on which they can be transported passively over long distances by surface currents (van der Baan and Holthuis 1969). Benthic populations of I. metallica are not known even though the species is reported from coastal waters in many parts of the world (Miller 1968; Hartmann 1976; Sano et al. 2003; Abelló et al. 2004), probably as a consequence of inferiority in interspecific competition with benthic species (Gutow and Franke 2003). Apparently, rafting is a specific and evolutionarily developed life style of $I$. metallica. Living close to the surface requires tolerance against changing physical and chemical conditions such as temperature and salinity or intensive UV-radiation (e.g. Cheng 1975; Herring 1969). 
In contrast to I. metallica, the predominantly benthic I. baltica is found rafting almost exclusively in coastal waters. Abundances are usually low offshore (Morris and Mogelberg 1973) indicating a poor ability for long distance rafting. Idotea baltica is almost entirely lacking on abiotic rafts which provide only little plant food (Gutow and Franke 2003).

In order to identify specific adaptations to the rafting life style, we compared in laboratory experiments behavioural and physiological characteristics in terms of locomotive activity and respiration rates as well as the nutritive demands of the obligate rafter I. metallica and the facultative rafter I. baltica. We hypothesize that I. metallica has evolved strategies that allow the species to persist under conditions of limited food availability in oligotrophic open oceans.

\section{Material and methods}

\section{Animals}

In order to avoid metabolic variation due to the reproductive state, all experiments were carried out with adult males rather than females. Isopods of the species I. metallica and I. baltica were obtained from mass cultures which were run routinely at the Marine Station Helgoland. Wet weight (WW) of the animals ranged from 130 to $230 \mathrm{mg}$ for I. metallica and from 100 to $300 \mathrm{mg}$ for I. baltica. During the experiments, the animals were exposed to a constant temperature of $16^{\circ} \mathrm{C}$ and a light-dark cycle of 16:8 h (06:00-22:00 local time).

\section{Activity}

Two aquaria (28 cm high, $35.5 \mathrm{~cm}$ wide, $19 \mathrm{~cm}$ deep) were equipped with a $2 \mathrm{~cm}$ sediment layer of fine sand and were filled with 101 of seawater. Each aquarium was furnished with two fragments $(10 \mathrm{~g}$ each) of the brown alga Fucus vesiculosus which served as both a substratum for the isopods to cling to and as food. Algal fragments were fixed in the aquaria with a thin cotton string to a tripod above the aquaria but were allowed to float on the water surface. The distance between both algal pieces was about $20 \mathrm{~cm}$. Two-day-old Artemia nauplii were offered as additional food.

One aquarium was equipped with ten individuals of I. metallica and the other with ten I. baltica. After $24 \mathrm{~h}$ of acclimation, the behaviour of the isopods was monitored three times per day at 11:00, 14:00 and 19:30 local time. Randomly selected animals were observed for $10 \mathrm{~s}$. Their locomotive activity was recorded and classified as "low", "medium" and "high" (see below). In total, 40 observations (10 s each) were done per species and monitoring period. Consequently, on average, each animal was recorded four times during each monitoring period. Five replicates with ten individuals each were performed for each species within 1 week. The total number of observations was 600 per species. After each experimental period, all individuals were returned to the mass culture.

Low activity: Sitting calmly on the substratum (sediment or algae), grooming antennae and pleopods, feeding algae, catching and feeding on Artemia nauplii (catch posture). Social contact: touch without movement

Medium activity: Slow movement (striding) on substratum (sediment or algae), turning/spinning around the body. Social contact: touch with movement

High activity: Swimming horizontally or vertically through the water, fast movement (running) on substratum (sediment or algae). Social contact: casing, scuffle, cannibalism

\section{Respiration}

Oxygen consumption rates were determined in a closed system by the Winkler method (Grasshoff 1983). Prior to the experiments, individuals of both species were kept separately for defecation in glass vials $(40 \mathrm{ml})$ for $12 \mathrm{~h}$ without food. Seawater was filtered $(0.2 \mu \mathrm{m})$, allowed to adjust overnight to the experimental temperature of $16^{\circ} \mathrm{C}$, and then filled into eight incubation bottles $(0.57-0.611)$. Six of these bottles contained 1 isopod $(3 \times 1$ I. metallica and $3 \times 1 \quad$ I. baltica) and a piece of gauze each. Two bottles served as controls. Animals were incubated for $4-5 \mathrm{~h}$ at $16^{\circ} \mathrm{C}$ before subsamples of the water were transferred into Winkler flasks $(50-60 \mathrm{ml})$ and fixed for the quantification of dissolved oxygen. The isopods were carefully blotted on filter paper and weighed (WW). The experiment was repeated four times resulting in a total number of 12 individuals per species. These experiments were conducted in the morning as well as in the afternoon.

\section{Food ingestion and egestion}

The animals were acclimated to the experimental conditions for 1 week. For acclimation, individual isopods were maintained individually in glass vials $(40 \mathrm{ml})$ and were fed with pieces of $F$. vesiculosus and Artemia nauplii in excess. The seawater was changed daily.

For experiments, 26 isopods of each species were fed individually with weighed pieces of $F$. vesiculosus and 200 Artemia nauplii. After $24 \mathrm{~h}$, the isopods were removed and WW of the animals was recorded. The remaining Fucus fragments were weighed and remaining Artemia nauplii were counted.

Faecal pellets of the animals were collected immediately after the experiments, transferred into reaction cups and centrifuged for $15 \mathrm{~min}$ at $13,000 \mathrm{~g}$ and $4^{\circ} \mathrm{C}$. Supernatants were removed and the pellets were weighed and lyophilised. Dry weight (DW) was measured for 
food items F. vesiculosus and Artemia nauplii as well as for the faeces.

\section{Biochemical investigations}

Digestive enzymes and total lipids were measured in aqueous extracts of individual adult males. Animals were lyophilised and then ground to a homogeneous fine powder. Sub-samples were suspended in Aqua dem. and homogenized by ultrasonication (Branson Sonifier Cell Disruptor B15).

Total protease activity was determined with azocasein as substrate. Samples $(20 \mu \mathrm{l})$ were incubated in reaction tubes with $200 \mu \mathrm{l}$ of $0.1 \mathrm{M}$ Tris/HCl-buffer for $5 \mathrm{~min}$ at $30^{\circ} \mathrm{C}$. The reaction was initiated with $50 \mu \mathrm{l}$ of azocasein solution $(1 \% \mathrm{w} / \mathrm{v}$ in buffer) and incubated for another $30 \mathrm{~min}$ at $30^{\circ} \mathrm{C}$ under permanent shaking. The reaction was terminated with $500 \mu \mathrm{l}$ of an aqueous solution of trichloroacetic acid (TCA, 8\%) and cooling on ice. The cups were centrifuged for $15 \mathrm{~min}$ at $15,000 \mathrm{~g}$ and $4^{\circ} \mathrm{C}$. The absorbance of the supernatant was read at $366 \mathrm{~nm}$. Tests and controls were run in triplicate. Controls received the samples after the addition of TCA. The activity was normalized to $1 \mathrm{~g}$ of DW $\left(\Delta E_{366} \mathrm{~min}^{-1} \mathrm{~g}_{\mathrm{DW}}^{-1}\right)$.

Amylase activity was measured with a commercial assay (Sigma Diagnostics 580). Fifty microlitre of animal extracts was added to $1 \mathrm{ml}$ of substrate solution and incubated at $30^{\circ} \mathrm{C}$ in a temperature-controlled cuvette holder. The increase of absorbance was continuously recorded for $3 \mathrm{~min}$. The activity was expressed as $\mathrm{U} \mathrm{g}_{\mathrm{DW}}^{-1}$ $\left(=\mu \mathrm{mol} \mathrm{min}{ }^{-1} \mathrm{~g}_{\mathrm{DW}}^{-1}\right)$. Six individuals of each species were analyzed.

The total amount of lipids in I. metallica and I. baltica were determined with the sulphophosphovanillin method after Zöllner and Kirsch (1962) using a commercial test kit (Merck, Merckotest 3321). The procedure was modified after Saborowski and Buchholz (1996) to be performed on microplates. Powder from freeze-dried isopods was first crudely homogenized in $2 \mathrm{ml}$ of water with an Ultraturrax and subsequently sonicated with an ultrasonic cell disrupter (Branson Sonifier B15). Aliquots of $40 \mu \mathrm{l}$ were transferred into $1.5 \mathrm{ml}$ chloroform:methanol $(2+1)$ and vortexed for $50 \mathrm{~min}$ at $25^{\circ} \mathrm{C}$. Thereafter, cups were centrifuged at $4^{\circ} \mathrm{C}$ and $15,000 \mathrm{~g}$ for $15 \mathrm{~min}$. The supernatants $(1.3 \mathrm{ml})$ were transferred into fresh cups and the organic solvent was evaporated at $45^{\circ} \mathrm{C}$ within $1 \mathrm{~h}$ (Eppendorf concentrator 5301). Sulphuric acid $(500 \mu \mathrm{l})$ was added to the remaining lipids and the samples were boiled for at least $10 \mathrm{~min}$. Standards of cholesterol $(0-150 \mu \mathrm{g})$ were treated in the same way. After cooling, $20 \mu \mathrm{l}$ of the samples were transferred in triplicate onto each of two microplates. Samples on the first microplate received $350 \mu$ of phosphoric acid and served as a blank. The second plate received $350 \mu \mathrm{l}$ of sulphuric acid/vanillin (Merckotest 3321). After $40 \mathrm{~min}$, both plates were read in a microplate reader at $530 \mathrm{~nm}$ (Dynatech, MR 7000). The sample plate was corrected for blank values.

\section{Statistics}

The distribution of the behaviour of the animals on different activity levels was analyzed with a $\chi^{2}$-text. A $t$ test was applied for comparing two normally distributed data sets (respiration rates, egestion rates and egestion:ingestion ratio, enzyme activities). If normal distribution failed, a Mann-Whitney $U$ test was applied instead (lipids). Linear regression lines of $\ln ($ rate +1$)$ transformed data were analyzed for similarity of slopes and intercepts with an ANCOVA (ingestion rates). Slopes of linear regressions were tested for deviation from zero with an $F$ test (respiration vs. body mass, egestion rates vs. body mass).

\section{Results}

\section{Locomotive activity}

Idotea metallica and I. baltica had significantly different activity patterns $\left(\chi^{2}\right.$-test: $\left.P<0.001\right)$. Idotea metallica showed low locomotive activity for about $85 \%$, medium activity for $10 \%$ and high activity for $5 \%$ of the observation period (Fig. 1). Idotea baltica showed low activity for $60 \%$, medium activity for $25 \%$ and high activity for about $15 \%$ of the time.

\section{Respiration}

No statistically significant differences were detected between oxygen consumption rates from different daytimes ( $t$ test: $P>0.05$ ) indicating no diurnal activity patterns under laboratory conditions. Consequently, respiration rates measured in the morning and in the afternoon were pooled for interspecific comparison.

In both species, respiration rates did not correlate with body mass. Average respiration rates were

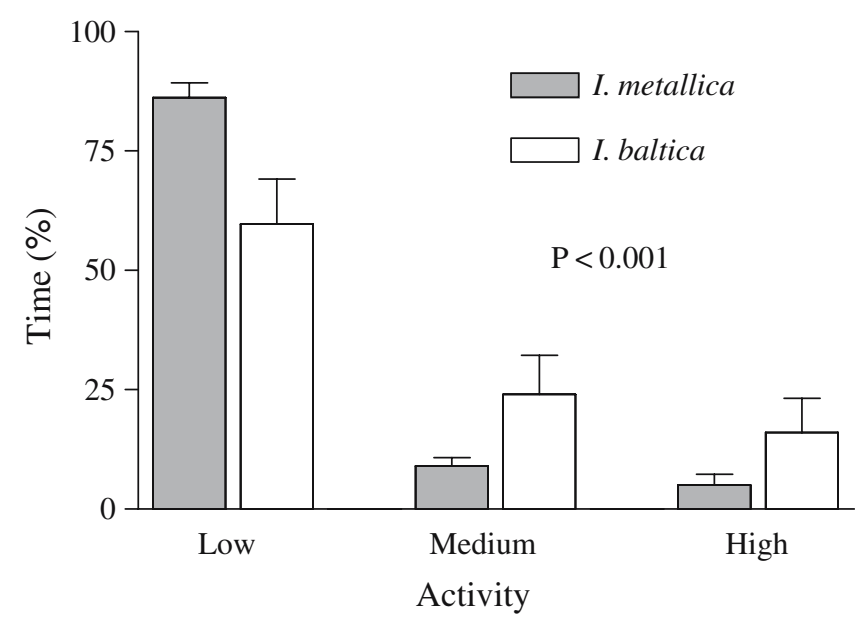

Fig. 1 Activity profiles of I. metallica and I. baltica $(n=600$ observations per species; means $\pm \mathrm{SD}$ ) 
$0.23 \pm 0.08 \mathrm{mg} \quad \mathrm{O}_{2} \mathrm{~g}_{\mathrm{WW}}^{-1} \mathrm{~h}^{-1}$ for I. metallica and $0.20 \pm 0.08 \mathrm{mg} \mathrm{O}_{2} \mathrm{~g}_{\mathrm{WW}}^{-1} \mathrm{~h}^{-1}$ for I. baltica (Fig. 2). The difference between both species was not significant ( $t$ test: $P>0.05)$.

Food ingestion and egestion

The relationship between body mass and ingestion rates was best described by a negative exponential regression model (Fig. 3, Table 1).

The overall weight-specific ingestion rates were on average 2.5 times higher in I. baltica than in I. metallica $(P<0.0001)$. Both species ingested more $F$. vesiculosus (Fig. 3a) than Artemia nauplii (Fig. 3b; $P<0.0001$ ). However, I. metallica ingested on average five times more algae than Artemia nauplii while I. baltica ingested 80 times more algae than Artemia nauplii. Ingestion of Artemia nauplii was higher in I. metallica than in I. baltica $(P<0.0001)$ while this was reverse for ingestion of $F$. vesiculosus $(P<0.0001)$.

In both species, the egestion rate was independent of the body mass (i.e. slope of linear regression did not significantly deviate from $0, F$ test: $P>0.05$ ). The average egestion rate was about eight times higher in I. baltica $\left(21.3 \pm 12.5 \mathrm{mg}_{\mathrm{DW}} \mathrm{g}_{\mathrm{WW}}^{-1} \mathrm{~d}^{-1}\right)$ than in I. metallica $\left(2.7 \pm 1.7 \mathrm{mg}_{\mathrm{DW}} \mathrm{g}_{\mathrm{WW}}^{-1} \mathrm{~d}^{-1}\right)$ (Fig. 4). The difference was statistically significant ( $t$ test: $P<0.0001)$.

Digestive enzymes and lipids

Total proteolytic activity amounted to $3.5 \pm 1.6$ $\Delta E \min ^{-1} \mathrm{~g}_{\mathrm{DW}}^{-1}$ in I. metallica (Fig. 5a). Idotea baltica showed significantly higher total proteinase activity $\left(7.4 \pm 3.9 \Delta E \mathrm{~min}^{-1} \mathrm{~g}_{\mathrm{DW}}^{-1}, t\right.$ test: $\left.P<0.0001\right)$. Amylase activity was $1.5 \pm 0.7 \mathrm{U} \mathrm{g}_{\mathrm{DW}}^{-1}$ in $I$. metallica and $7.9 \pm 4.9 \mathrm{U} \mathrm{g} \mathrm{g}_{\mathrm{DW}}^{-1}$ in I. baltica (Fig. 5b). Again, average activity was significantly higher in $I$. baltica than in I. metallica ( $t$ test: $P<0.0001)$.

Both species differed significantly (Mann-Whitney $U$ test: $P=0.003$ ) in the total lipid content (Fig. 6). While

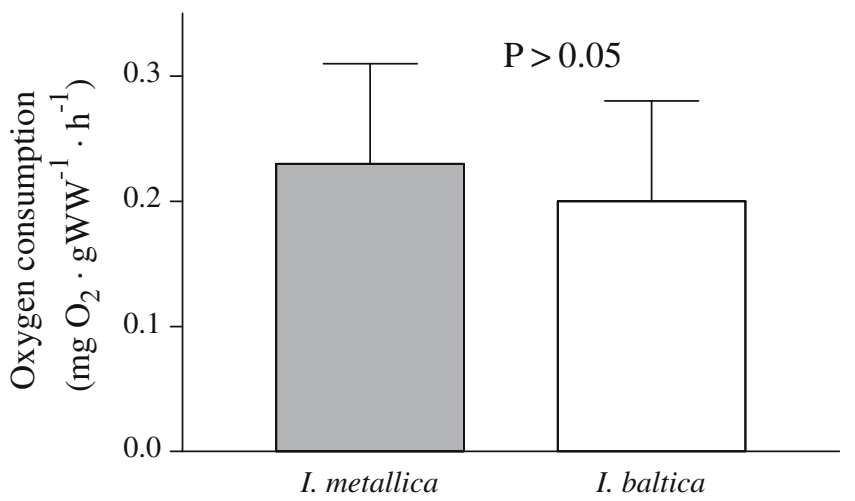

Fig. 2 Oxygen consumption rates of I. metallica and I. baltica $(n=12$ per species, means $\pm \mathrm{SD})$ total lipid content in I. metallica amounted to $15.9 \pm 5.6 \% \mathrm{DW}$, that in I. baltica was $9.8 \pm 1.5 \% \mathrm{DW}$.

\section{Discussion}

Both isopod species I. metallica and I. baltica have repeatedly been collected from objects floating on the sea surface (Thiel and Gutow 2005a). Idotea metallica is an obligate rafter. The species is often found on abiotic floating objects far offshore (Aliani and Molcard 2003) but also on biotic objects such as macroalgae and wood (Gutow and Franke 2003) which served as natural substrata before the widespread occurrence of manmade debris in the world's oceans. Idotea baltica, in contrast, is a facultative rafter that is largely restricted to coastal waters where it rafts preferably on detached macroalgae (Ingólfsson 1995, 2000). Our results revealed behavioural and physiological characteristics of I. metallica and I. baltica that help to identify specific adaptations to the rafting life style.
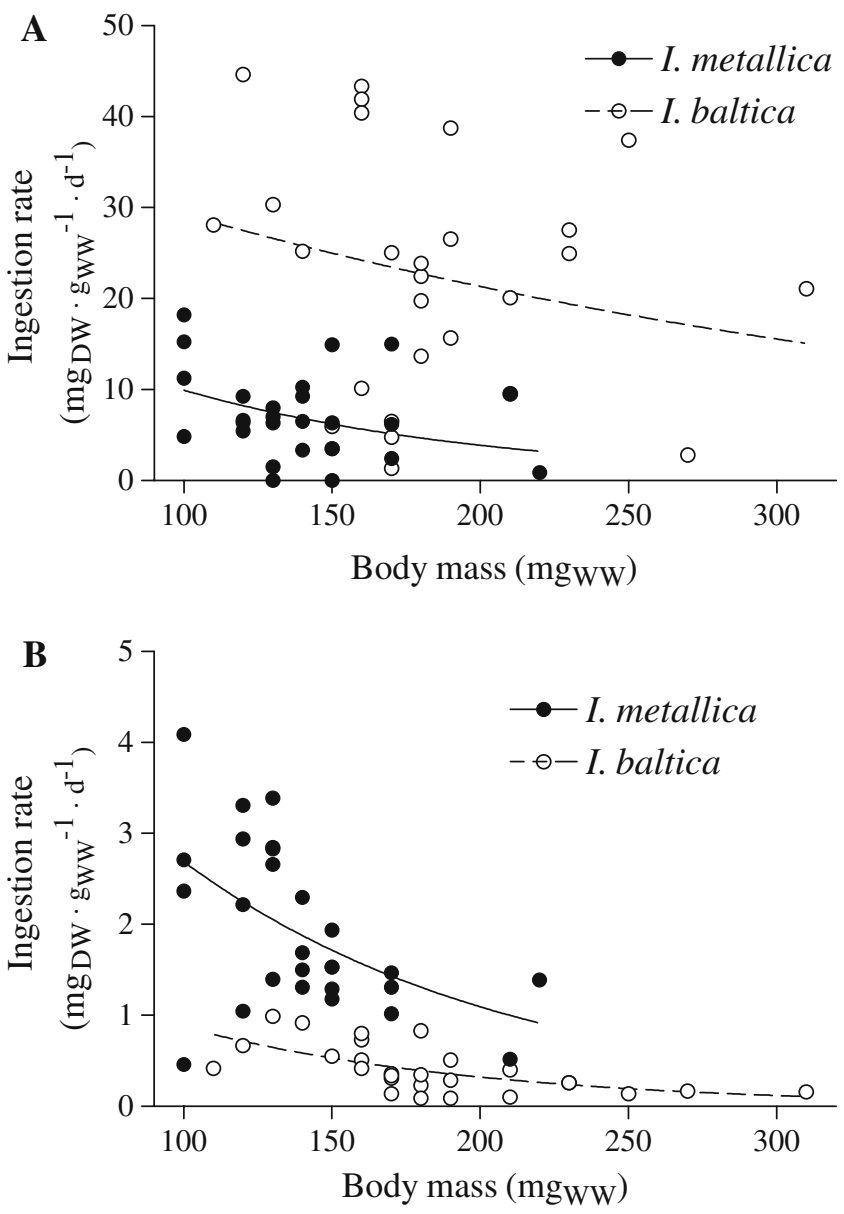

Fig. 3 Ingestion rates of I. metallica and I. baltica for (a) Fucus vesiculosus and (b) Artemia nauplii ( $n=26$ per species) 
Table 1 Equations and $R^{2}$ values of non-linear regressions of weight-specific ingestion rates presented in Fig. 3

\begin{tabular}{llll}
\hline Food & Species & Equation & $R^{2}$ \\
\hline Fucus vesculosus & I. metallica & $\mathrm{f}(x)=25.44 \times \mathrm{e}^{(-0.009 x)}$ & 0.102 \\
& I. baltica & $\mathrm{f}(x)=40.17 \times \mathrm{e}^{(-0.003 x)}$ & 0.046 \\
Artemia nauplii & I. metallica & $\mathrm{f}(x)=6.61 \times \mathrm{e}^{(-0.009 x)}$ & 0.274 \\
& I. baltica & $\mathrm{f}(x)=2.38 \times \mathrm{e}^{(-0.010 x)}$ & 0.383 \\
\hline
\end{tabular}

Behaviour

Idotea metallica showed low swimming activity remaining close to the substratum. For about $90 \%$ of the observed time, the animals were sitting on their substratum and feeding. Idotea baltica, in contrast, showed higher activity with more frequent movements on the substratum, sediment and algae, and within the water column.

Idotea metallica occurs mainly in offshore waters where densities of floating items are usually much lower than in coastal waters (Thiel et al. 2003; Thiel and Gutow 2005b). Even though I. metallica is capable of active swimming, locomotive performance is poor compared to pelagic organisms such as fishes. Once separated from their raft, the animals are unlikely to successfully colonize a new floating object. Probably, leaving the raft will rapidly lead to death by exhaustion as a consequence of extended swimming in search of a substratum. However, a higher probability of colonizing a new substratum in offshore waters may be given where floating items accumulate in surface fronts of gyres or Langmuir circulations (Thiel and Gutow 2005b).

The preferred habitats of $I$. baltica are subtidal macroalgae (Hemmi and Jormalainen 2002). They provide both food and shelter from predators. Idotea baltica is capable of leaving this benthic habitat actively to escape from severe intra- or interspecific competition (Franke and Janke 1998). Passive dislocation appears along with macroalgae that become detached from their substratum and float to the surface. The animals can frequently migrate between floating and attached

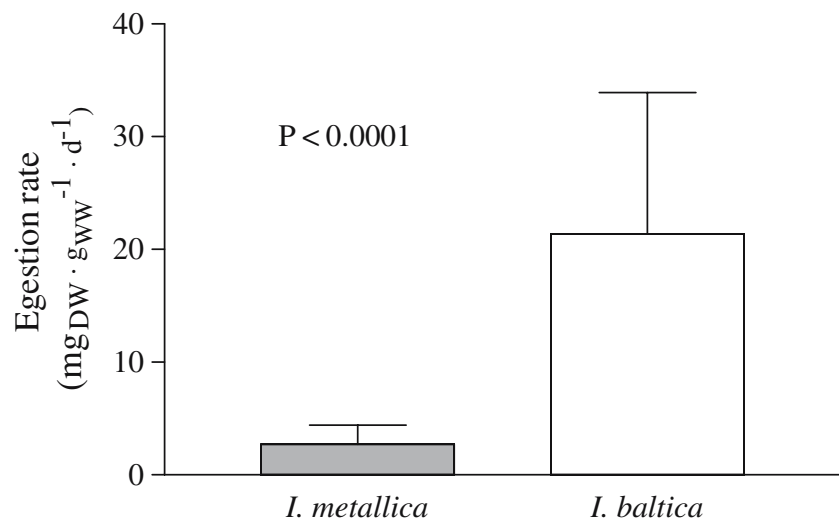

Fig. 4 Egestion rates of I. metallica and I. baltica $(n=26$ per species, means $\pm \mathrm{SD}$ )
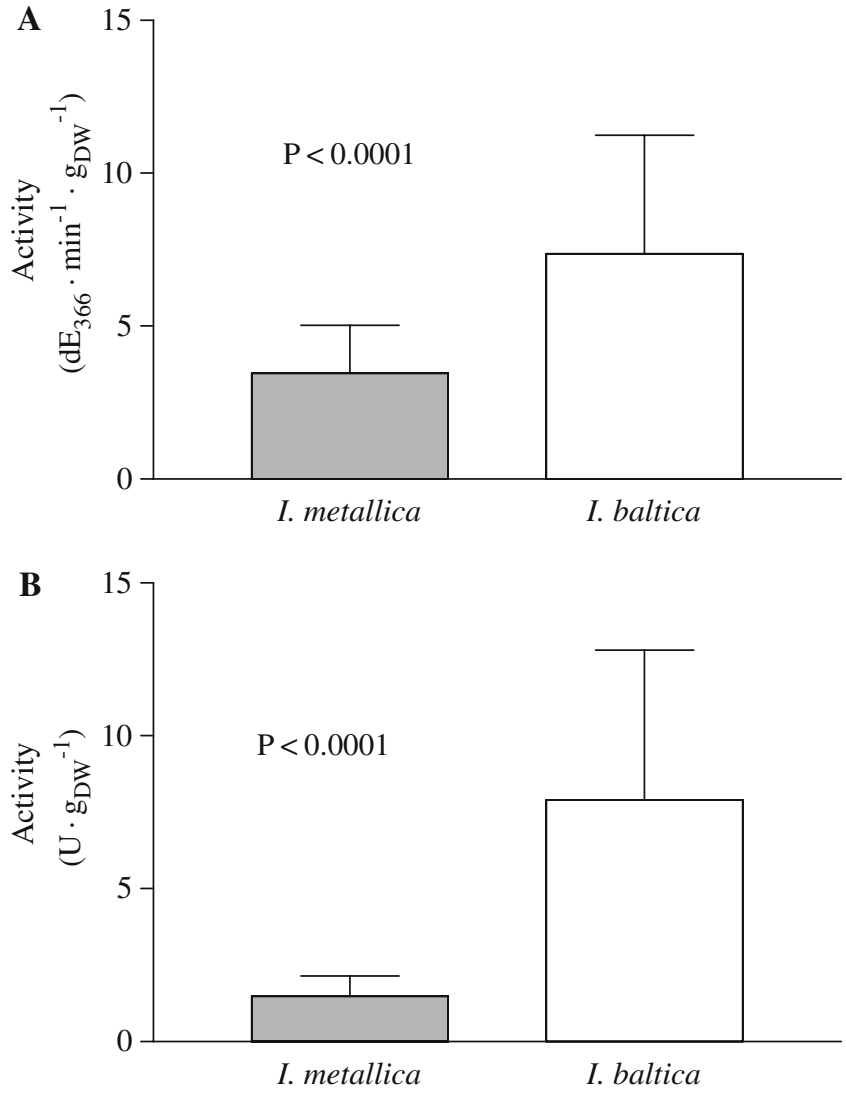

Fig. 5 Proteinase (a) and amylase (b) activity in I. metallica and I. baltica $(n=12$ per species, means $\pm \mathrm{SD})$

macroalgae in shallow coastal waters to return to the preferred subtidal habitat. Excursions in the pelagic environment are not risky when floating substrata are abundant and where shallow waters allow for easy exchange between the neuston and the benthos.

\section{Respiration}

The difference in activity level between the two species was not reflected in the oxygen consumption rates. At $16^{\circ} \mathrm{C}$, both species consumed about $0.2 \mathrm{mg} \mathrm{O}_{2} \mathrm{~g}_{\mathrm{WW}}^{-1} \mathrm{~h}^{-1}$. The results on respiration rates do not contradict the observations on the behaviour. In order to reduce the activity of the animals, each respiration chamber was equipped with a piece of gauze where the animals could cling to. Accordingly, due to the experimental design, we measured standard metabolic rates rather than activity levels.

Data on oxygen consumption rates of Idotea spec. published previously were measured with different methods and under various conditions in terms of experimental temperatures, shape and size of respiration chambers (Table 2). Our results for I. baltica are in the same range as those of Bulnheim (1974) who also equipped the respiration chambers with a piece of gauze to keep the animals calm. Respiration rates measured by 


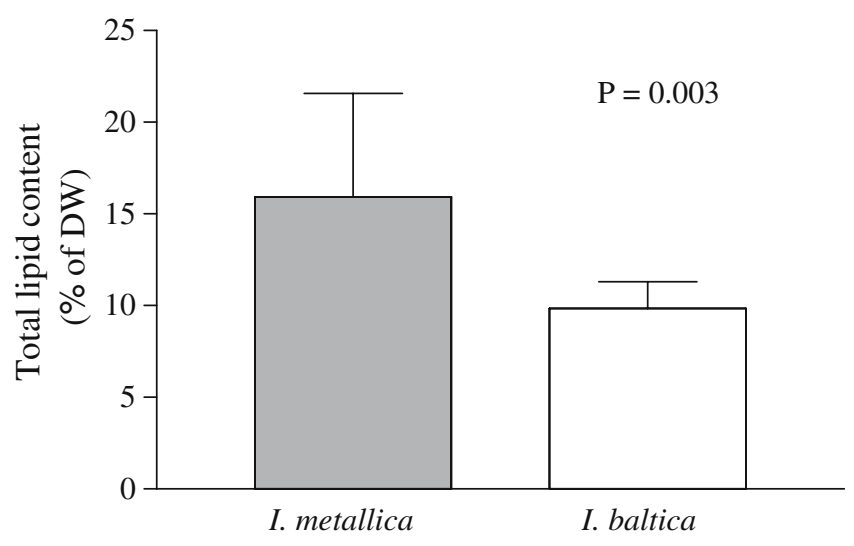

Fig. 6 Total lipid content of I. metallica $(n=10)$ and I. baltica $(n=6$, means $\pm \mathrm{SD})$

Vetter et al. (1999) for I. baltica and I. emarginata were exceptionally high. The authors incubated groups of seven animals in a $670 \mathrm{ml}$ oxystat system. The high density of animals might have caused stress and, thus, stimulated the respiratory activity of the isopods.

Assuming an average respiratory quotient (RQ) of 0.85 , the consumed oxygen equals to about $70 \mu \mathrm{g}$ $\mathrm{C} \mathrm{g}_{\mathrm{WW}}^{-1} \mathrm{~h}^{-1}$ and to about $8.3 \mathrm{mg}_{\mathrm{DW}}$ food $\mathrm{g}_{\mathrm{WW}}^{-1} \mathrm{~d}^{-1}$. The amount of food (WW) needed per individual isopod would then amount to $11.2 \mathrm{mg} \mathrm{d}^{-1}$ in I. metallica and $12.3 \mathrm{mg} \mathrm{d}^{-1}$ in I. baltica. This calculation was done for different average sizes of either species and is based on the assumption that the average carbon value of food items amounts to $30 \% \mathrm{DW}$ and assimilation efficiency is $66 \%$ (Strong and Daborn 1979). In the following section, these theoretical demands will be compared with the food ingestion rates obtained from our feeding experiments.

Feeding, ingestion and egestion

In our experiments, food was offered in excess and may have stimulated the feeding activity of both species. The amount of food consumed by I. metallica covered almost exactly the metabolic energy demands as calculated from oxygen consumption rates. In I. baltica, however, average food consumption was more than two times higher than needed to cover standard metabolic demands. Apparently, a significant amount of ingested food was not assimilated. Idotea metallica seems to treat and to utilize food more economically than I. baltica. In I. metallica, faeces amounted to about $40 \%$ of the mass of ingested food while I. baltica released about $90 \%$ of the ingested food, indicating a more efficient food resorption by I. metallica than by I. baltica. Accordingly, feeding of $I$. baltica appears rather sloppy and "wasteful" compared to I. metallica.

Both species also showed different food preferences. Idotea metallica fed more intensively on zooplankton (i.e. Artemia nauplii) than did I. baltica. The ability to capture and to utilize planktonic food sources makes I. metallica less dependent on autochthonous food resources of the raft. Idotea baltica, in contrast, consumed much more algal material than I. metallica. The present data confirm the results of Gutow (2003) who found that I. baltica destroys algal patches 6-14 times faster than I. metallica. He concluded that intensive feeding on algal rafts leads to rapid habitat destruction which is the major threat for rafting populations of Idotea. Idotea baltica lives under conditions of excessive food supply and may not face food limitation. Consequently, the feeding habits of I. baltica appear unsuited for long-term rafting on abiotic rafts where food supply is highly sporadic or on floating macroalgae that could be rapidly destroyed.

\section{Digestive enzymes}

To determine the potential for digestion in both species, we measured the activities of representative enzymes which hydrolyze proteins and carbohydrates. Activities of both protease and amylase were lower in I. metallica than in I. baltica. According to Jones et al. (1997) and Le

Table 2 Oxygen consumption of various Idotea species measured by different authors

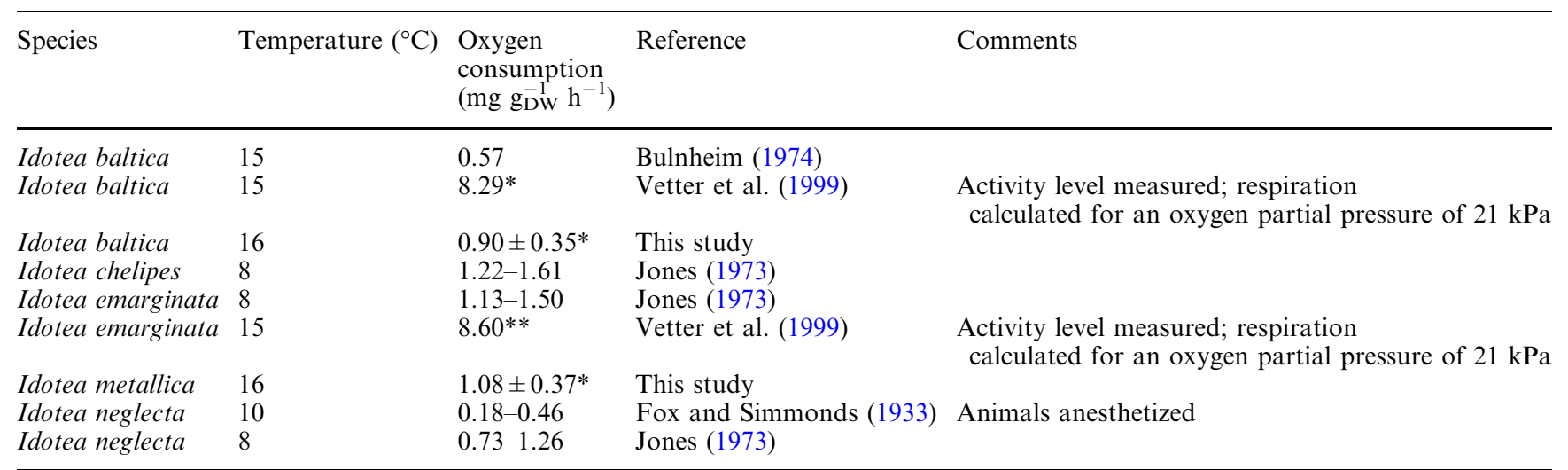

*DW amounted to $21 \%$ of WW in I. metallica and $22 \%$ of WW in I. baltica

**For I. emarginata, we applied the WW to DW ratio of I. baltica 
Vay et al. (2001), elevated proteolytic activities, represented as trypsin, appear in planktonic crustaceans and crustacean larvae feeding herbivorously. Trypsin activities were lowest in carnivorous and omnivorous species. Additionally, herbivorous feeders may have high ingestion rates and short gut retention times which result in high turnover rates (Kurmaly et al. 1989). Apparently, a similar pattern seems to apply for the Idotea species studied here.

Idotea metallica showed a more carnivorous feeding behaviour and ingested more then twice the amount of Artemia nauplii than I. baltica. Omnivorous and, particularly, carnivorous species can cover their demand of nitrogen and essential amino acids rapidly from the protein-rich diet. Accordingly, comparatively low proteolytic activities are sufficient to cover the metabolic needs. The efficiency of assimilation may be further improved by long gut retention times as indicated by low ingestion and low egestion rates (Boehlert and Yoklavich 1984). This strategy is more suited to carnivorous encounter feeding on less abundant but digestible and energy-rich prey (Le Vay et al. 2001).

Idotea baltica, in contrast, consumed predominantly Fucus algae. Algal diets, however, are poorer in nitrogen and proteins than zooplankton such as Artemia nauplii. Accordingly, elevated proteolytic activities are required to release sufficient proteins for covering metabolic demands. Simultaneously, feeding rates must increase to supply the digestive tract with sufficient quantities of digestible proteins. Surplus material has to be egested. Thus, high proteolytic and amylase activities and rapid food turnover may be a strategy of I. baltica to maximize energy assimilation in environments with abundant food of low nitrogen and protein content.

\section{Storage products}

Lipids belong to the most important organic storage products in crustaceans. High lipid levels were found in zooplankton from temperate and polar latitudes as well as from the deep sea while taxa from tropical and subtropical regions showed low lipid amounts (reviewed by Hagen and Auel 2001).

In isopods, lipids are predominantly accumulated in the midgut gland, in apidocytes, in the pericard and in the entire hemocoel (Biesiot et al. 1999). Idotea metallica showed higher total lipid content than did I. baltica. As the latter species might be affected by low food availability while rafting through open ocean waters, body lipid reserves might help I. metallica to better sustain periods of starvation. Although high lipid contents can be expected in animals from polar regions, adult males of Mesidotea entomon contained only 8\% DW total lipids (Korczynski 1989). This is only about half of the lipid content of I. metallica, indicating that the latter species is well adapted to variable food availability and, thus, periods of starvation. Accordingly, I. metallica must be expected to be less affected by starvation than I. baltica.

\section{Conclusions}

Idotea baltica is adapted to living in shallow coastal waters where macroalgae provide food and shelter in excess. Low protein concentrations of the food and low assimilation efficiency increase food consumption rates. On algal rafts, high feeding rates cause rapid destruction of the floating substratum which, in turn, limits rafting performance. Consequently, I. baltica occurs only accidentally far offshore but is mainly retained in coastal waters near its apparently unlimited benthic food resources.

Idotea metallica, in contrast, has developed efficient strategies to gain, store and save energy in the open ocean where food is often limited because of oligotrophic conditions (Longhurst et al. 1995). The more pronounced feeding on protein-rich zooplankton makes I. metallica widely independent of the autochthonous food resources of its raft. Efficient nutrient assimilation covers the energetic demands of the animals. Periods of starvation can be compensated by metabolizing internal lipid stores. Consequently, I. metallica is able to colonize abiotic floating objects such as plastics (Aliani and Molcard 2003) that provide only low autochthonous food resources. These are highly durable in the marine environment and allow for the establishment of persistent local populations and, finally, successful dispersal via rafting over large oceanic distances.

\section{References}

Abelló P, Guerao G, Codina M (2004) Distribution of the neustonic isopod Idotea metallica in relation to shelf-slope frontal structures. J Crust Biol 24:558-566

Aliani S, Molcard A (2003) Hitch-hiking on floating marine debris: macrobenthic species in the Western Mediterranean Sea. Hydrobiologia 503:59-67

Biesiot PM, Wang SY, Perry HM, Trigg C (1999) Organic reserves in the midgut gland and fat body of the giant deep-sea isopod Bathynomus giganteus. J Crust Biol 19:450-458

Boehlert GW, Yoklavich MM (1984) Carbon assimilation as a function of ingestion rate in larval pacific herring, Clupea harengus pallasi Valenciennes. J Exp Mar Biol Ecol 79:251-262

Bulnheim H-P (1974) Respiratory metabolism of Idotea balthica (Crustacea, Isopoda) in relation to environmental variables, acclimation process and moulting. Helgoländer Meeresunters 26:464-480

Cheng L (1975) Marine pleuston - animals at the sea-air interface. Oceanogr Mar Biol 13:181-212

Fox HM, Simmonds BG (1933) Metabolic rates of aquatic arthropods from different salinities. J Exp Biol 10:67-78

Franke H-D, Gutow L, Janke M (1999) The recent arrival of the oceanic isopod Idotea metallica Bosc off Helgoland (German Bight, North Sea): an indication of a warming trend in the North Sea? Helgoländer Meeresunters 52:347-357

Franke H-D, Janke M (1998) Mechanisms and consequences of intra- and interspecific interference competition in Idotea baltica (Pallas) and Idotea emarginata (Fabricius) (Crustacea: Isopoda): a laboratory study of possible proximate causes of habitat segregation. J Exp Mar Biol Ecol 227:1-21 
Grasshoff K (1983) Determination of oxygen. In: Grasshoff K, Ehrhardt M, Kremling K (eds) Methods of seawater analysis. Verlag Chemie, Weinheim, pp 61-72

Gutow L (2003) Local population persistence as a pre-condition for large-scale dispersal of Idotea metallica (Crustacea, Isopoda) on drifting habitat patches. Hydrobiologia 503:59-67

Gutow L, Franke H-D (2001) On the current and possible future status of the neustonic isopod Idotea metallica Bosc in the North Sea: a laboratory study. J Sea Res 45:37-44

Gutow L, Franke H-D (2003) Metapopulation structure of the marine isopod Idotea metallica, a species associated with drifting habitat patches. Helgoland Mar Res 56:259-264

Hagen W, Auel H (2001) Seasonal adaptations and the role of lipids in oceanic zooplankton. Zoology 104:313-326

Hartmann J (1976) Der Jahresgang von Neuston im Golf von Neapel. Int Rev Ges Hydrobio 61:825-840

Hemmi A, Jormalainen V (2002) Nutrient enhancement increases performance of a marine herbivore via quality of its food algae. Ecology 83:1052-1064

Herring PJ (1969) Pigmentation and carotinoid metabolism of the marine isopod Idotea metallica. J Mar Biol Assoc UK 49:766-779

Ingólfsson A (1995) Floating clumps of seaweed around Iceland: natural microcosms and a means of dispersal for shore fauna. Mar Biol 122:13-21

Ingólfsson A (2000) Colonization of floating seaweed by pelagic and subtidal benthic animals in southwestern Iceland. Hydrobiologia 440:181-189

Jones MB (1973) Survival and oxygen consumption in various salinities of three species of Idotea (Crustacea, Isopoda) from different habitats. Comp Biochem Physiol 48A:501-506

Jones DA, Kumlu M, Le Vay L, Fletcher DJ (1997) The digestive physiology of herbivorous, omnivorous and carnivorous crustacean larvae: a review. Aquaculture 155:285-295

Korczynski RE (1989) Biochemical composition of the isopod Mesidotea entomon (Linnaeus) from the western Arctic. Polar Biol 9:391-395

Kurmaly K, Yule AB, Jones DA (1989) An energy budget for the larvae of Penaeus monodon (Fabricius). Aquaculture 81:13-25

Le Vay L, Jones DA, Puello-Cruz AC, Sangha RS, Ngamphongsai $C$ (2001) Digestion in relation to feeding strategies exhibited by crustacean larvae. Comp Biochem Physiol 128A:623-630

Longhurst A, Sathyendranath S, Platt T, Caverhill C (1995) An estimate of global primary production in the ocean from satellite radiometer data. J Plankton Res 17:1245-1271
Miller MA (1968) Isopoda and Tanaidacea from buoys in coastal waters of the continental United States, Hawaii, and the Bahamas (Crustacea). Proc US Nat Mus 125:1-53

Moreira PS (1972) Species of marine Isopoda (Crustacea, Peracarida) from Southern Brazil. Bolm Inst Oceanogr S Paulo 21:163-179

Morris BF, Mogelberg DD (1973) Identification manual to the pelagic Sargassum fauna. Bermuda Biol Stat Spec Publ 11:1-63

Naylor E (1972) British Marine Isopods. Linn Soc Synopsis of the British Fauna (new series) No. 3. Academic, London

Saborowski R, Buchholz F (1996) Annual changes in the nutritive state of North Sea dab. J Fish Biol 49:173-194

Sano M, Omori M, Taniguchi K (2003) Predator-prey systems of drifting seaweed communities off the Tohoku coast, northern Japan, as determined by feeding habitat analysis of phytal animals. Fish Sci 69:260-268

Strong KW, Daborn GR (1979) Growth and energy utilisation of the intertidal isopod Idotea baltica (Pallas) (Crustacea: Isopoda). J Exp Mar Biol Ecol 41:101-123

Thiel M, Gutow L (2005a) The ecology of rafting in the marine environment. II. The rafting organisms and community. Oceanogr Mar Biol 43:279-418

Thiel M, Gutow L (2005b) The ecology of rafting in the marine environment. I. The floating substrata. Oceanogr Mar Biol 42:181-263

Thiel M, Hinojosa I, Vasquez N, Macaya E (2003) Floating marine debris in coastal waters of the SE-Pacific (Chile). Mar Poll Bull 46:224-231

Tully O, O Céidigh P (1986) The ecology of Idotea species (Isopoda) and Gammarus locusta (Amphipoda) on surface driftweed in Galway Bay (West of Ireland). J Mar Biol Assoc UK 66:931-942

van der Baan SM, Holthuis LB (1969) On the occurrence of Isopoda in the surface plankton in the North Sea near the lightship "Texel". Neth J Sea Res 4:354-363

Vetter R-A, Franke H-D, Buchholz F (1999) Habitat-related differences in the responses to oxygen deficiencies in Idotea baltica and Idotea emarginata (Isopoda, Crustacea). J Exp Mar Biol Ecol 239:259-272

Zöllner N, Kirsch K (1962) Über die quantitative Bestimmung von Lipoiden (Mikromethode) mittels der vielen natürlichen Lipoiden (allen bekannten Plasmalipoiden) gemeinsamen Sulphophosphovanillin-Reaktion. Z Gesamte Exp Med 135:545-56 